Int. J. Morphol.,

32(2):715-720, 2014.

\title{
Morphology and Histochemistry of the Liver of Carnivorous Fish Hemisorubim platyrhynchos
}

\author{
Morfología e Histoquímica del Hígado del Pez Carnívoro Hemisorubim Platyrhynchos
}

\author{
Claudemir Kuhn Faccioli",**; Renata Alari Chedid",***; Maria Terezinha Siqueira Bombonato*; \\ Carlos Alberto Vicentini* \& Irene Bastos Franceschini Vicentini*
}

FACCIOLI, C. K.; CHEDID, R. A.; BOMBONATO, M. T. S.; VICENTINI, C. A. \& VICENTINI, I. B. F. Morphology and histochemistry of the liver of carnivorous fish Hemisorubim platyrhynchos. Int. J. Morphol., 32(2):715-720, 2014.

SUMMARY: The aim of this study was to characterize the normal structure of the liver of Hemisorubim platyrhynchos, a carnivorous freshwater catfish found in Neotropical region, using gross anatomy, histology and histochemistry. Anatomically, the liver presents C-shaped and only two lobes: smaller right and bigger left. The gallbladder is located in right lobe and shows elongated shaped. Histological analysis demonstrated that the hepatic parenchyma is made of two hepatocytes plates surrounded by sinusoids. The hepatocytes are polygonal-shaped cells, with spherical nucleus and a dark prominent nucleolus. The cytoplasm presents large amount of lipids and glycogen deposits PAS positives. There are no hepatic lobules or portal triads. Bile ducts are lined by columnar epithelial cells with apical mucosubstances PAS and $\mathrm{AB}$ positive. Furthermore, the liver presents melano-macrophages centers, distributed next to the blood vessels and bile ducts, constituted by cells accumulating pigments, whose presence may be related to the nutritional status of the fish. Moreover pancreatic tissue was observed in visceral portion of liver, formed by exocrine pancreatic tissue and islet organ, constituting an extrahepatic pancreas.

KEY WORDS: Anatomy; Histology; Hepatocytes; Extrahepatic Pancreas; Teleost.

\section{INTRODUCTION}

The fish liver appears as a key organ, which controls many functions and plays an important role in fish physiology, both in anabolism as in catabolism (Bruslé \& Anadon, 1996). The size, shape and volume of liver are adapted to the available space between other visceral organs of general cavity (Bertolucci et al., 2008). According to Bruslé \& Anadon, although there are variations between the species, the liver of teleosts in general presents three lobes. The main cellular type of the liver is the hepatocytes which are arranged as cords forming cellular plates, each of which separates several lacunae: the vascular (sinusoids) and biliary (canaliculi) network (Eurell \& Haensly, 1982; Bruslé \& Anadon; Bombonato et al., 2007).

The fish liver also presents the melano-macrophages, which are distinctive groupings of pigment-containing cells that are usually organized in melano-macrophage centers (Hartley et al., 1996). Melano-macrophage centers increase in size or frequency in conditions of environmental stress and have been suggested as reliable biomarkers for water quality in terms of both deoxygenation and iatrogenic chemical pollution (Agius \& Roberts, 2003).
Fishes are very susceptible to environmental variations and respond significantly to pollution. The fish liver is a very interesting model. It is considered a target organ for the study of interactions among environmental factors and structure and/or hepatic functions (Bruslé \& Anadon). In this sense, the morphological characteristics of the liver have been associated with physiological status in fish (Caballero et al., 1999) and used as an indicator of environmental quality (Rocha et al., 1994; Al-Youseif et al., 2000; Gochfeld, 2003).

Hemisorubim platyrhynchos belongs to the family Pimelodidae and Siluriformes order. This is a migratory species without parental care that is widely distributed in the Neotropical region. Reports indicate its presence in the Orinoco, Amazon, Paraguay, Uruguay and Paraná River basins. According to Bressan et al. (2009), these are nocturnal carnivorous fish that has been a reduction in the population size due to habitat destruction as a result of the building of hydroelectric dams that interrupt the flow of migration required for reproduction. This species is valuable for aquaculture because of the quality and flavor of its meat

* Department of Biological Sciences, São Paulo State University - UNESP, Bauru, SP, Brazil.

** Institute of Biosciences, Letter and Exact Sciences, São Paulo State University - UNESP, São José do Rio Preto, SP, Brazil.

**** Aquaculture Center of UNESP - CAUNESP, São Paulo State University - UNESP, SP, Brazil. 
and the absence of intramuscular bones. Thus, the aim of this study was to describe the morphological and histochemical characteristics of the liver of $H$. platyrhynchos, with the goal of increasing available knowledge of the morphofunctional aspects in carnivorous Neotropical fish, especially to improve the aquaculture.

\section{MATERIAL AND METHOD}

Animals. Fifteen adult specimens of $H$. platyrhynchos, with a body length of $35.2 \pm 2.3 \mathrm{~cm}$, were obtained from Piraí Pisciculture (Terenos, State of Mato Grosso do Sul, Brazil). The animals were anesthetized and euthanized with an overdose of benzocaine and then were dissected with a longitudinal incision along the ventral region. The present study was approved by the Ethical Committee for Research of the Faculty of Sciences at São Paulo State University UNESP, Bauru, SP, Brazil, under protocol nº 1144/46/01/10.

Gross anatomy. The features of liver were analyzed and photo-documented in situ with others organs of the digestive tract. Posteriorly, the liver of five specimens was removed and dissected to analysis and documentation using a Leica M50 stereomicroscope (Germany) and stored in $10 \%$ formalin.

Histological and histochemical studies. Tissue fragments of the liver of ten specimens were fixed in Bouin's solution immediately after dissection. After fixation, the samples were washed with $70 \%$ ethanol, dehydrated in graded ethanol solutions and embedded in historesin. Histological sections $(2-3 \mathrm{~mm})$ were stained with hematoxylin-eosin (HE) and $1 \%$ toluidine blue (TB). For histochemical studies the samples were embedded in paraplast and sections (5-7 $\mathrm{mm}$ ) were submitted to reactions with Alcian blue (AB) at pH 1.0 and 2.5 and periodic acid-Schiff (PAS) (Suvarna et al., 2012). The sections were analyzed and photodocumented using Olympus BX50 microscope (Japan).

\section{RESULTS}

Gross anatomy. The liver of $H$. platyrhynchos is located in the cranial region of the general cavity, cranially to stomach and anterior intestine (Fig. 1A). The liver presents a reddish-brown color, $\mathrm{C}$-shaped and is divided in two lobes. The right one is smaller than the left lobe, and is near the gallbladder. The left lobe presents gastric imprint (Figs. 1A-1C). Gallbladder possesses elongated shape and bluegreen color. The visceral face of the liver presents a tissue of light color, where the portal vein and bile duct are located, surrounded mainly by pancreatic tissue (Fig. 1C).

Histological and histochemical studies. Histological sections of the liver show a parenchyma covered by a thin capsule of connective tissue lined with a simple squamous epithelium (Fig. 1F). The hepatic parenchyma is made of two cellular plates surrounded by sinusoids. Each plate shows polarized hepatocytes with a sinusoidal face that can be considered the basal region of hepatocyte, and a biliary face that can be the apical region of hepatocyte. Between two neighboring sinusoids, the hepatocytes are arranged as cords that can have two cells thick or can present branches and/or anastomoses of cords (Figs. 1F and 1G). The liver shows no triads or lobules division, but presents an organization of the sinusoids converging to the center-lobular vein (Figs. $1 \mathrm{~F}$ and $1 \mathrm{G})$. The hepatocytes are polygonal-shaped cells, with spherical nucleus usually centrally located and a prominent dark central nucleolus. The cytoplasm is eosinophilic and presents large amount of lipids. With histochemical analysis with PAS reaction, glycogen deposits were identified in the cytoplasm of the hepatocytes.

The pancreatic tissue in $H$. platyrhynchos was observed in the visceral face of the liver and gradually invades the liver along the branches of the portal vein (Figs. 1D and 1E). However, pancreatic tissue was not observed in hepatic parenchyma. The exocrine pancreatic tissue consists of clusters of pyramidal cells mostly organized in acini. The acinar cells have a dark basophilic cytoplasm, distinct basal nucleus and many eosinophilic zymogen granules. Moreover the pancreas also presents the endocrine tissue as islet organ (Fig. 1D).

The center-lobular veins present simple squamous epithelium, while the arterioles possess a simple cubic epithelium. The bile system consists of bile canaliculi and ducts. The bile canaliculi were observed in the apical border of the neighboring hepatocytes, toward the bile ducts. The bile ducts consist of a simple colunar epithelium (Fig. 1H). In the cytoplasm of the epithelial cells of the bile ducts it was observed a strong reaction of PAS and a moderate reaction of $\mathrm{AB}$ pH 1.0 and 2.5 (Figs. 1I and 1J).

The hepatic parenchyma also presents the melanomacrophage centers, located around the blood vessels and bile ducts (Figs. 1H-1J). Melano-macrophage centers are usually nodular and are lined by a thin connective tissue that enters the organ as septa. The macrophages of melanomacrophage centers present a small peripheral nucleus. It is observed many dark pigments in the cytoplasm of these cells, mainly in the periphery of the melano-macrophage centers. With PAS technique, the macrophages present weak intensity of reaction (Fig. 1I). 


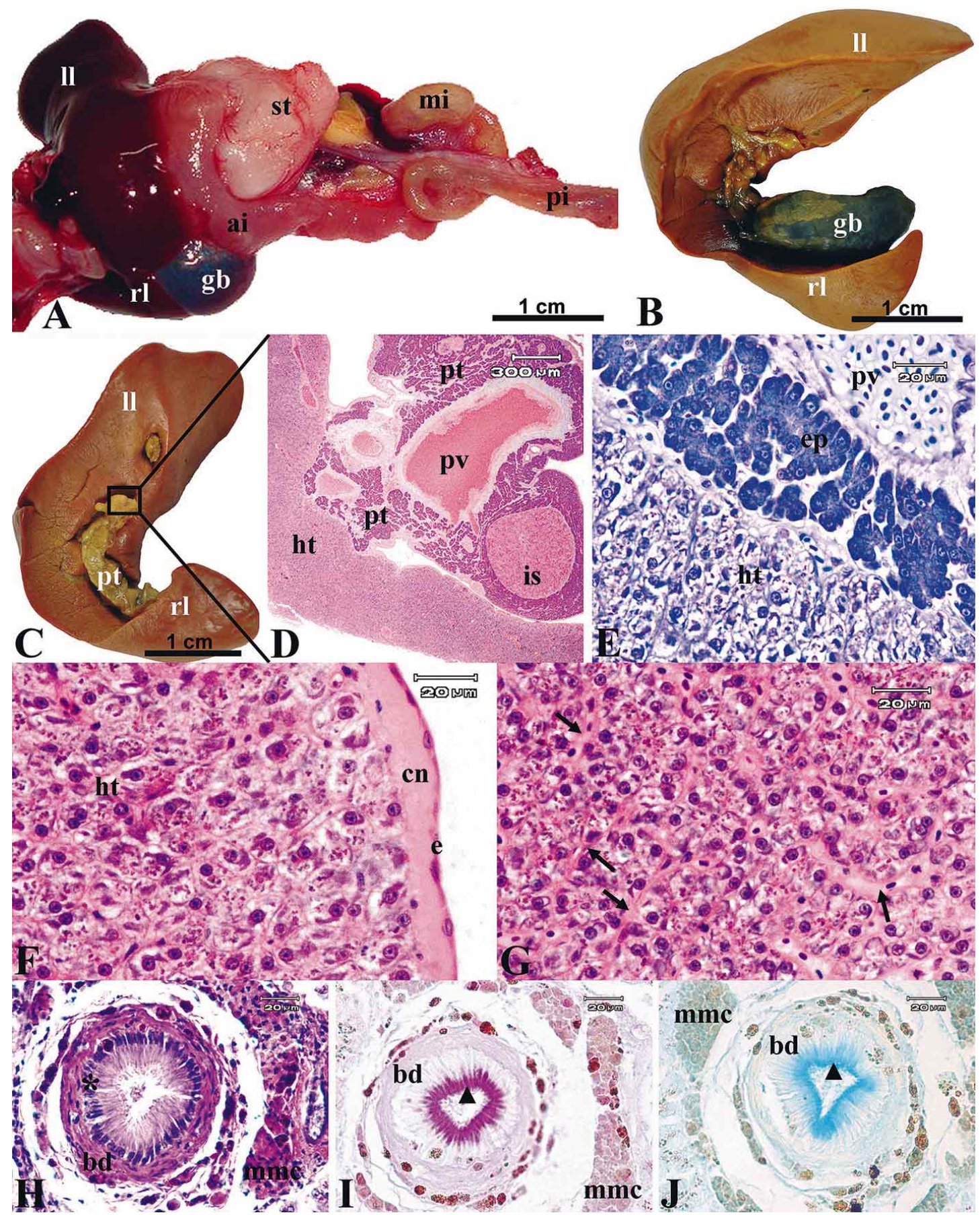

Fig. 1. A: Digestive system of Hemisorubim platyrhynchos. B: Ventral view of the liver, showing the right lobe (rl), left lobe (11) and elongated gallbladder (gb). C: Visceral face of the liver, note the pancreatic tissue (pt). D: Histological section of the transition of the hepatic tissue (ht) to the pancreatic tissue (pt) (HE). E: Histological section of the hepatic tissue (ht) and the exocrine pancreatic tissue (ep) (AT). F: Transversal section of the liver evidencing the squamous epithelium (e), connective tissue (cn) and hepatocytes (HE). G: Hepatic parenchyma with hepatocytes cords, evidencing the sinusoids (arrows) (HE). H: Transversal section of the liver, evidencing the bile duct (bd) with simple columnar epithelium with basal nucleus (asterisk) and melano-macrophage centers (mmc) (HE). I: Bile duct (bd) showing apical region of the epithelial cells with PAS-positives mucosubstances (arrowhead). J: AB-positives mucosubstances (arrowhead) in apical region of the epithelial cells of bile duct (bd). Legend: ll-left lobe; rl-right lobe; gb-gallbladder; st-stomach; ai-anterior intestine; mi-middle intestine; pi-posterior intestine; is-islet organ; mmcmelano-macrophage centers; ht-hepatic tissue, pt-pancreatic tissue, pv-portal vein. 


\section{DISCUSSION}

The liver of Hemisorubim platyrhynchos is divided into two lobes, different of what was observed in other Neotropical fishes, as Hoplias malabaricus (Lemes \& Braccini, 2004), Leporinus macrocephalus (Bombonato et al.), Astyanax altiparanae (Bertolucci et al.), who possess three lobes. In the specie studied, the liver shows reddish brown color due to the rich vascularity, indicating that the animals were in good nutritional status and in normal health (Bruslé \& Anadon).

The basic histological constitution of the liver is highly conserved among species and is similar in many teleosts (Kendall \& Hawkins, 1975; Brusle \& Anadon). In the liver parenchyma of $H$. platyrhynchos, the hepatocytes are arranged in cords and it was no division in lobules and portal triads was observed, as evidenced in other teleosts (Kendall \& Hawkins; Hampton et al., 1985; Gonzalez et al., 1993; Vicentini et al., 2005; Bombonato et al.; Bertolucci et al.). The hepatocytes of $H$. platyrhynchos are polygonal and present basal nucleus and apical cytoplasm with few glycogen granules but large amount of lipids, similar to observed in Sparus aurata (El-Bakary \& El-Gammal, 2010). In Oligosarcus jenynsii, Petcoff et al. (2006), observed that the hepatocytes are polyhedral cells with spherical nucleus and according to Bucke et al. (1984), these cells are specialized in the accumulation of reserve substances, mainly glycogen and lipids.

Alongside the hepatocytes cords of H. platyrhynchos, sinusoids containing blood plasma converge on the centerlobular vein. According El-Bakary \& El-Gamma, the hepatocytes-sinusoidal structure is physiologically important, not only because hepatocytes takes up large molecules from the sinusoid, but also because a large number of macromolecules are secreted into the sinusoid. The bile ducts of $H$. platyrhynchos present simple columnar epithelium with apical mucosubstances PAS and AB positives. The occurrence of neutral and acid mucosubstances at the apex of the epithelial cells of the bile ducts can be indicative of a protective function, important to prevent possible injuries caused by hepatocytes secretions.

The melano-macrophage centers of the liver of the H. platyrhynchos are located near the blood vessels and bile ducts. Díaz et al. (1999) reported the melano-macrophage centers near hepatic arteries, bile ducts and hepatopancreas in liver of the Cynoscion guatucupa. However, in Hoplias malabaricus (Lemes \& Braccini) and Leporinus macrocephalus (Bombonato et al.) these centers were observed only near blood vessels. The melano-macrophage centers of the $H$. platyrhynchos present many dark pigments, mainly in peripheral cells. In Cynoscion guatucupa, this tissue presented lipofuscin, ceroid and melanin pigments (Díaz et al.). According to Agius \& Roberts, melanomacrophage centers usually contain a variety of pigments, including melanin, and these increase in range and volume in older fish or in the presence of diseases. Hartley et al., concluded that these centers are critical elements of the immune system of fish, including immune response against foreign materials such as altered cells or infectious agents.

The pancreatic tissue in H. platyrhynchos is observed in the visceral portion of the liver and gradually invades the liver along the branches of the portal vein. The fish pancreas is generally diffusely spread within the fat and mesenteries that connect the intestine, stomach, liver and gallbladder (Youson et al., 2006). The exocrine pancreatic tissue develops around the portal vein during ontogenesis and can remain extrahepatic or penetrate more or less deeply into the liver parenchyma depending on the fish species (Bruslé \& Anadon). Although the exocrine pancreatic tissue of $H$. platyrhynchos penetrates in the liver in some regions, acini were note observed in the hepatic parenchyma, constituting an extrahepatic pancreas, unlike what was observed in other teleosts as Oligosarcus jenynsii (Petcoff et al.), Ictalurus punctatus (Kendall \& Hawkins), Oreochromis niloticus (Vicentini et al.), Leporinus macrocephalus (Bombonato et al.), Astyanax altiparanae (Bertolucci et al.). The exocrine pancreatic tissue produces digestive enzymes, such as trypsin, amylase and carboxypeptidase $\mathrm{A}$, that are delivered to the digestive tract through a network of ducts (Field et al., 2003). Islet organ also was observed in pancreatic tissue of H. platyrhynchos and, according to Beccaria et al. (1990), there are four principal cell types in the islet organ of fishes: cells-A producing glucagon-like, cells-B producing insulin, cells-D producing somatostatin, and cells-PP which secrete the pancreatic polypeptide The presence or absence of these cell types is of interest from the point of view of both the ontogenetic and phylogenetic history of this tissue among fishes (Youson et al.).

The results obtained in this study enabled the characterization of the normal structure of the liver of $H$. platyrhynchos, assisting in the analysis of adverse conditions, such as water contamination, nutritional status and health of fishes, which cause changes in the normal structure of the liver (Hartley et al.; Ruiz-Picos \& López-López, 2012).

ACKNOWLEDGEMENTS. The authors thank the Laboratory of Morphology Aquatic Organism (Faculty of Sciences/UNESP, Bauru). This research was supported by grants from Fundação de Amparo à Pesquisa do Estado de São Paulo-FAPESP, under protocol nº. 2010/02842-0. 
FACCIOLI, C. K.; CHEDID, R. A.; BOMBONATO, M. T. S.; VICENTINI, C. A. \& VICENTINI, I. B. F. Morfología e histoquímica del hígado del pez carnívoro Hemisorubim platyrhynchos. Int. J. Morphol., 32(2):715-720, 2014.

RESUMEN: El objetivo de este estudio fue caracterizar la estructura normal del hígado de Hemisorubim platyrhynchos, un bagre carnívoro de agua dulce encontrado en la región neotropical, utilizando anatomía macroscópica, histología e histoquímica de mucosustancias. Anatómicamente, el hígado presenta una forma de C y sólo dos lóbulos de tamaño diferente: menor derecho y mayor izquierdo. La vesícula biliar se encuentra en el lóbulo derecho y presenta forma alargada. El análisis histológico demostró que el parénquima hepático está hecho de dos placas de hepatocitos rodeados por sinusoides. Los hepatocitos son células poligonales con núcleo esférico y un nucléolo oscuro prominente. El citoplasma presenta gran cantidad de lípidos y depósitos de glucógeno PAS positivos. No hay lóbulos hepáticos o triadas portal. Los conductos biliares están revestidos por células columnares epiteliales con mucosustancias apicales PAS y AB positivos. Además, el hígado presenta centros de melanomacrófagos, distribuidos junto a los vasos sanguíneos y conductos biliares, constituidos por células que acumulan pigmentos, cuya presencia puede estar relacionada con el estado nutricional de los peces. Por otra parte, el tejido pancreático se observó en la porción visceral de hígado, formado por tejido pancreático exocrino y órgano islote, que constituye un páncreas extrahepático.

\section{PALABRAS CLAVE: Anatomía; Histología; Hepatocitos; Páncreas Extrahepático; Teleósteos.}

\section{REFERENCES}

Agius, C. \& Roberts, R. J. Melano-macrophage centres and their role in fish pathology. J. Fish Dis. 26(9):499-509, 2003.

Al-Yousuf, M. H.; El-Shahawi \& Al-Ghais, S. M. Trace metals in liver, skin and muscle of Lethrinus lentjan fish species in relation to body length and sex. Sci. Total Environ., 256(2-3):87-94, 2000 .

Bertolucci, B.; Vicentini, C. A.; Franceschini-Vicentini, I. B. \& Bombonato, M. T. S. Light microscopy and ultrastructure of the liver of Astyanax altiparanae Garutti and Britski, 2000 (Teleostei, Characidae). Acta Sci. Biol. Sci., 30(1):73-6, 2008.

Beccaria, C.; Diaz, J. P.; Gabrion, J. \& Connes, R. Maturation of the endocrine pancreas in the sea bass, Dicentrarchus labrax L. (Teleostei): an immunocytochemical and ultrastructural study. I. Glucagon-producing cells. Gen. Comp. Endocrinol., 78(1):8092, 1990.

Bombonato, M. T. S.; Rochel, S. S.; Vicentini, C. A. \& FranceschiniVicentini, I. B. Estudo morfológico do tecido hepático de Leporinus macrocephalus. Acta Sci. Biol. Sci., 29(1):81-5, 2007.

Bressan, P. M.; Kierulff, M. C. M. \& Sugieda, A. M. Fauna ameaçada de extinção do estado de São Paulo: Vertebrados. São Paulo, Fundação Parque Zoológico de São Paulo, Secretaria do Meio Ambiente, 2009. pp. 646.

Bruslé, J. \& Anadon, G. G. The structure and function of fish liver. In: Munshi, J. S. D. \& Dutta, H. M. (Eds.). Fish Morphology. North-Holland, Science Publishers, 1996. pp.77-93.

Bucke, D.; Watermann, B. \& Feist, S. Histological variations of hepato-splenic organs from the North Sea dab, Limanda limanda (L.). J. Fish Dis., 7(4):255-68, 1984.
Caballero, M. J.; López-Calero, G.; Socorro, J.; Roo, F. J.; Izquierdo, M. S. \& Férnandez, A. J. Combined effect of lipid level and fish meal quality on liver histology of gilthead seabream (Sparus aurata). Aquac., 179(1-4):277-90, 1999.

Díaz, A. O.; González Castro, M.; García, A. M.; Devincenti, C. V. \& Goldemberg. A. L. Morphological and histochemical characterization of liver from stripped weakfish, Cynoscion guatucupa (Cuvier, 1830). Biocienc., 7(1):67-78, 1999.

El-Bakary, N. E. R. \& El-Gammal, H. L. Comparative Histological, Histochemical and Ultrastructural Studies on the Liver of Flathead Grey Mullet (Mugil cephalus) and Sea Bream (Sparus aurata). Global Vet., 4(6):548-53, 2010.

Eurell, J. A. \& Haensly, W. E. The histology and ultrastructure of the liver of Atlantic croaker Micropogon undulatus L. J. Fish Biol., 21(1):113-25, 1982.

Field, H. A.; Dong, P. D.; Beis, D. \& Stainier, D. Y. Formation of the digestive system in zebrafish. II. Pancreas morphogenesis. Dev. Biol., 261(1):197-208, 2003.

Gochfeld, M. Cases of mercury exposure, bioavailability, and absorption. Ecotoxicol. Environ. Saf., 56(1):174-9, 2003.

Gonzalez, G.; Crespo, S. \& Brusle, J. Histo-cytological study of the liver of the cabrilla sea bass, Serranus cabrilla (Teleostei, Serranidae), an available model for marine fish experimental studies. J. Fish. Biol., 43(3):363-73, 1993.

Hampton, J. A.; McCuskey, P. A.; McCuskey, R. S. \& Hinton, D. E. Functional units in rainbow trout (Salmo gairdneri) liver: I. Arrangement and histochemical properties of hepatocytes. Anat. Rec., 213(2):166-75, 1985. 
FACCIOLI, C. K.; CHEDID, R. A.; BOMBONATO, M. T. S.; VICENTINI, C. A. \& VICENTINI, I. B. F. Morphology and histochemistry of the liver of carnivorous fish Hemisorubim platyrhynchos. Int. J. Morphol., 32(2):715-720, 2014.

Hartley, W. R.; Thiyagarajah, A. \& Treinies, A. M. Liver lesions in the gar fish (Lepisosteidae) as biomarkers of exposure. Mar. Environ. Res., 42(1-4):217-21, 1996.

Kendall, M. W. \& Hawkins, W. E. Hepatic Morphology and Acid Phosphatase Localization in the Channel Catfish (Ictalurus punctatus). J. Fish. Res. Board Can., 32(8):1459-1464, 1975.

Lemes, A. S. \& Braccini, M. C. Descrição e análise histológica das glândulas anexas do trato digestório de Hoplias malabaricus (Bloch, 1794), (Teleostei, Erythrinidae). Biodivers. Pampeana, 2(1):33-41, 2004.

Petcoff, G. M; Díaz, A. O.; Escalante, A. H. \& Goldemberg, A. L. Histology of the liver of Oligosarcus jenynsii (Ostariophysi, Characidae) from Los Padres Lake, Argentina. Iheringia, Sér. Zool., 96(2):205-8, 2006.

Rocha, E.; Monteiro, R. A. \& Pereira, C. A. The liver of the brown trout, Salmo trutta fario: a light and electron microscope study. J. Anat., 185(Pt. 2):241-9, 1994.

Ruiz-Picos, R. \& López-López, E. Gill and liver histopathology in Goodea atripinnis Jordan, related to oxidative stress in Yuriria Lake, Mexico. Int. J. Morphol., 30(3):1139-49, 2012.

Suvarna, K. S.; Layton, C. \& Bancroft, J. D. Bancroft's Theory and Practice of Histological Techniques. $7^{\text {th }}$ ed., London, Churchill Livingstone, 2012.

Vicentini, C. A.; Franceschini-Vicentini, I. B.; Bombonato, M. T. S.; Bertolucci, B.; Lima, S. G. \& Santos, A. S. Morphological study of the liver in the teleost Oreochromis niloticus. Int. J. Morphol., 23(3):211-6, 2005.

Youson, J. H.; Al-Mahrouki, A. A.; Amemiya, Y.; Graham, L. C.; Montpetit, C. J. \& Irwin, D. M. The fish endocrine pancreas: review, new data, and future research directions in ontogeny and phylogeny. Gen. Comp. Endoc., 148(2):105-15, 2006.

\section{Correspondence to:} Irene Bastos Franceschini Vicentini Department of Biological Sciences Faculty of Sciences São Paulo State University - UNESP Bauru, São Paulo BRAZIL

Email address: ibfv@fc.unesp.br

Recibido : 11-02-2014

Aceptado: 12-05-2014 